\title{
Developing Bamboo Fraction Media for Teaching Fractions in Elementary School Level
}

\author{
Tria Mardiana ${ }^{1 *}$, Ari Suryawan ${ }^{1}$, Ismah $^{2}$, Rahmita Nurul Muthmainah ${ }^{2}$, \\ Nurbaity Widyasari ${ }^{2}$
}

\author{
${ }^{1}$ Department of Elementary Teacher Education, University of Muhammadiyah Magelang, Magelang, Indonesia \\ ${ }^{2}$ Faculty of education, Muhammadiyah University of Jakarta, Indonesia \\ *Corresponding author. Email: triamardiana@ummgl.ac.id
}

\begin{abstract}
Development of appropriate media for students in understanding the basic concepts of fractions is needed. This study aims to generate mathematical learning media in the form of Bamboo Fraction on the material fractions to elementary school students. Method development in this research using the 4D model, namely: define (user analysis, curriculum, and teaching materials), design (designing products with tools and materials), develop (assessment and revision), and disseminate (the trial to potential users). The research instrument was a questionnaire. The assessment team consisted of products: experts, peer, teacher elementary school, and elementary school students' responses. This research has resulted in media Bamboo Fraction math learning to help students understand the basic concepts of fractions. Researchers have produced a mathematical learning media Bamboo Fraction on the material fractions to elementary school third grade students. Expert assessment of the product got a score of 428 and a percentage of $85.6 \%$, with very good category. Elementary third grade student responses to the instructional media of mathematics Bamboo Fraction obtained a score of 444 with a percentage of $88.8 \%$ votes. The value is in the interval is very good. Keywords: Bamboo Fraction media, teaching fraction, elementary school
\end{abstract}

\section{INTRODUCTION}

Math is a subject that is needed by students to solve everyday problems. Problem-solving ability is characterized by the ability of students to interpret a problem, plan a strategy as a solution, strategy implementation and check the answers [1] [2]. Submission of Mathematics in schools, implemented through learning activities, Learning in schools can be as good as the delivery of a learning resource teachers can provide students with a good understanding [3].

Learning mathematics is the study of the concept of number and space. If talking about the concept of numbers either integers and fractions it is no doubt that the majority of our daily conversation will get acquainted and often hear the words and see the writing numeral numbers [4]. One of the sub materials in mathematics is about fractions. Fractional material for learning basic level in Indonesia are from low grade to high grade. However, fractions of material is one of materials that cannot be Easily understood by elementary school students [5] [6]. Fractions occurs because the body is divided into several equal parts and the parts that have a fractional value [7]. Learning fractions requires a reorganization of numerical knowledge [8].

The background of this study because of the difficulty of elementary level students in understanding the concept of fractions in SD Muhammadiyah Borobudur. Problems occurred in the third class associated introduction of fractions up to the stage to compare. Such material as a basic knowledge of the material fractions, leading to further fragment the material level. However, the concept of fractional comparative analysis, there is a problem $\frac{3}{4}$ greater than $\frac{5}{9}$. In terms of numbers, children 5 and 9 considers that a greater than 3 and 4 . When the students were asked related reasons or explanations, there was confusion on the student about it.

During this time teachers teach without any media yet, when the introduction of teaching material fractions, teachers only describe the shapes on the board. However, because it is only used as an example and prior knowledge, then the given image is not much. As only, $\frac{1}{2} ; \frac{3}{4}$; and $\frac{2}{5}$, if to show the distribution of over 5 rarely done because when the draw will take a long time.

Another problem that arises when providing an understanding of equality associated fractions, or related fractional rank. For example, $\frac{2}{4}=\frac{1}{2}$. Not all children can understand both these fractions can be worth the same. When asked about why, the child cannot answer correctly, others did not want to answer because they do not know. Background of the problem, researchers developed a medium that can facilitate teachers in teaching, as well as help facilitate the understanding of the students, especially the lower class in learning the basic concepts of material fractions. To help the teachers' activities, need to apply the tools. One aspect that cannot be separated from the learning process is the use of media [4] [9].

Learning media is a tool that serves to convey a message of learning. Learning is a process of communication between students, teachers, and teaching materials. Communication 
will not run without the help of conveying a message or media [3] [10]. Media learning is everything that Becomes a means of delivering information from the sender to the recipient so that what is delivered can be well received [11]. Learning is a process of communication between learners, teachers, and teaching materials. Media becomes a component of learning resources or physical vehicle containing instructional materials for students that can stimulate learners to learn [12]. Learning media has important roles in learning activity Because It facilitates the teachers to deliver the materials to the students in learning activities [13].

Media developed by researchers in the form of Bamboo Fraction. The main ingredients are chosen to make the media is bamboo. Simply put, Bamboo Fraction are pieces of bamboo are arranged neatly on a stanchion, with parts measured. Bamboo is used in the development of the media, is a source of renewable building materials and widely available in Indonesia. From about 1250 species of bamboo in the world, 140 species or $11 \%$ of them are native to Indonesia [14]. Number bamboo fairly widely available in Indonesia, including Central Java, Bamboo rods do not like another tree because it has a hollow structure (blank) on the inside [14]. Bamboo as a raw material that is easy to split, shaped and easy process, besides that it is relatively cheap compared to wood raw material [15]. Because of this structural bamboo was chosen by researchers as a raw material for the media.

\section{METHOD}

This research used research and development ( $R$ \& D) method. Research and development is a process or steps to develop new products, or to improve the existing products [16]. The development of research applying the four steps of the study. This development using the 4D model, namely: define (analysis of user characteristics, curriculum, and teaching materials), design (designing products with tools and materials), develop (assessment and revision), and disseminate (the trial to potential users) [17].

The instrument used to collect data regarding the quality of the products are: First, the questionnaire sheet-shaped check list to get an assessment of experts that includes peer review and teachers. Aspects of learning media assessment criteria used were: 1) a material aspect, 3) aspects of an activity or experiment, 4) aspects of enforceability, 5) aspects of the display. Second, the questionnaire sheet-shaped check list used to obtain student response data. Aspects of the response criteria of students gathered in this study were: 1) Ease of understanding of the lesson, 2) The interest in the media, 3) The usefulness of the media, and 4) Ease of use. Third, documentation of various documents required in this study, such as the scope of the material fractions in elementary school for the lower classes, the teacher data. Mechanical analysis of data on product quality test aims to determine the quality of learning based on expert feedback media material, media experts, and a reviewer group consisting of 2 lecturers and 2 of primary school teachers. Then, the test data analysis techniques are limited to elementary school students that aims to determine the effectiveness of instructional media based on student responses. Students' response to learning media analyzed with descriptive analysis.

\section{RESULT AND DISCUSSION}

Based on the research design and development that have been put forward, the development of instructional media is done in four stages of development (the 4D model), namely:

\subsection{User Characteristics Analysis, Curriculum and Instructional Materials (Define)}

Target analysis conducted are the characteristics of learners, learning tools and teaching materials available. The results are found in the field, some students are less interested in studying mathematics, this is because students think that mathematics is a difficult subject. Material fractions in mathematics is one of finding the elusive mathematical material by students at the elementary level. Associated with the media, are not yet available special media for learning the material fractions. Related to the business development of the media, not many teachers who innovate in developing the media in accordance with the basic material needs of the learning material fractions.

\subsection{Designing products with Tools and Materials (Design)}

In designing mathematical learning media products Bamboo Fraction do several steps, namely: a) Mapping the basic competencies and learning objectives, b) Design building material, c) designing a model of the structure of the media, and d) Determining the assessment tool. The concept design of products used in the diagram 1 .

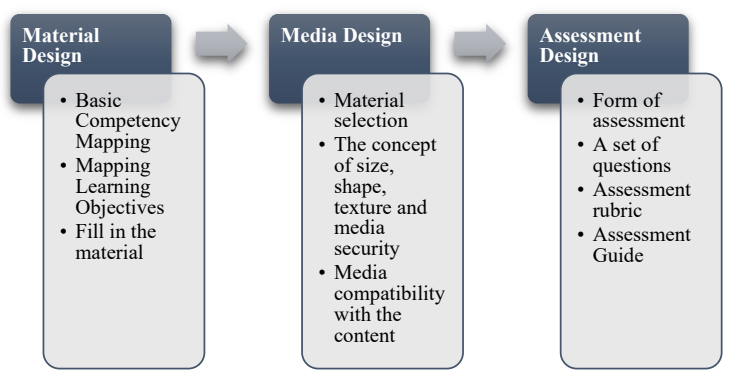

Figure 1 Product Design Concept Media

\subsection{Assessment and Revision (develop)}

After successfully designed a product design based on a design that has been created, researchers involved mathematical matter experts and media experts to assess the product. This is to test the feasibility of the use of media. Subject matter experts to give some input on the media. The feedback from subject matter experts in table 1. 
Table 4 Calculation of Assessment Criteria

Table 1 Advice from Expert Content

\begin{tabular}{|llcc|}
\hline No. & \multicolumn{1}{c|}{ Feedback } & Follow-up \\
\hline $\mathbf{1}$ & $\begin{array}{l}\text { Coverage of the material } \\
\text { reproduced }\end{array}$ & $\begin{array}{c}\text { It is already } \\
\text { done }\end{array}$ \\
\hline $\mathbf{2}$ & $\begin{array}{l}\text { Instructions for use further } \\
\text { clarified and specified }\end{array}$ & $\begin{array}{c}\text { It is already } \\
\text { done }\end{array}$ \\
\hline $\mathbf{3}$ & Reproduced evaluation questions & $\begin{array}{c}\text { It is already } \\
\text { done }\end{array}$ \\
\hline
\end{tabular}

Media experts in this study a lot to give input related to the raw material structure and media. The advice and input from media experts can be shown by Table 2 .

Table 2 Expert Advice from the Media

\begin{tabular}{|llc|}
\hline No. & \multicolumn{1}{c|}{ Feedback } & Follow-up \\
\hline $\mathbf{1}$ & $\begin{array}{l}\text { The tip is more refined bamboo } \\
\text { pieces }\end{array}$ & $\begin{array}{c}\text { It is already } \\
\text { done }\end{array}$ \\
\hline $\mathbf{2}$ & $\begin{array}{l}\text { Staining is trimmed } \\
\text { It is already } \\
\text { done }\end{array}$ \\
\hline $\mathbf{3}$ & $\begin{array}{l}\text { The number of pieces of } \\
\text { bamboo is propagated to } \\
\text { multiply the fractional variation }\end{array}$ & $\begin{array}{c}\text { It is already } \\
\text { done }\end{array}$ \\
\hline
\end{tabular}

After media products rated by the experts, the product improved based on suggestions and input of experts. Media that has been rectified then continued assessment involving the reviewer is 2 lecturers and 2 of primary school teachers. Learning media quality assessment covers several aspects, namely the attractiveness of the media, the ease of use of the media, the attractiveness of the display media, media effectiveness, ease of understanding the material. The results of the peer review assessment can be observed in table 3 .

Table 3 Result Analysis by Reviewers

\begin{tabular}{|llcc|}
\hline No. & \multicolumn{1}{c|}{ Aspect } & $\begin{array}{c}\text { total } \\
\text { Ratings }\end{array}$ & $\begin{array}{c}\text { The } \\
\text { percentage of } \\
\text { votes per } \\
\text { aspect }\end{array}$ \\
\hline $\mathbf{1}$ & $\begin{array}{l}\text { the attractiveness of } \\
\text { the media }\end{array}$ & 85 & $85 \%$ \\
\hline $\mathbf{2}$ & $\begin{array}{l}\text { ease of use of the } \\
\text { media }\end{array}$ & 87 & $90 \%$ \\
\hline $\mathbf{3}$ & $\begin{array}{l}\text { the attractiveness of } \\
\text { the display media }\end{array}$ & 84 & $91 \%$ \\
\hline $\mathbf{4}$ & $\begin{array}{l}\text { media effectiveness } \\
\mathbf{5}\end{array}$ & 85 & $85 \%$ \\
\hline & $\begin{array}{l}\text { ease of } \\
\text { understanding of } \\
\text { the material }\end{array}$ & 87 & $87 \%$ \\
\hline & & 428 & $85.6 \%$ \\
\hline
\end{tabular}

Based on Table 3, an overall assessment carried out by the reviewer points out that the quality of mathematics learning media Bamboo Fraction has a category Very Good (SB), with a bunch of total yield 428 votes $(X>420)$, with a percentage of $85.6 \%$. The categorization is based on the calculation results ideal criteria that can be observed in Table 4 .

\begin{tabular}{|llcc|}
\hline No. & $\begin{array}{c}\text { Quantitative Score } \\
\text { Range }\end{array}$ & Category & $\begin{array}{c}\text { Score } \\
\text { range }\end{array}$ \\
\hline $\mathbf{1}$ & $\mathrm{X}>\mathrm{Mi}+1.8 \mathrm{Sbi}$ & $\begin{array}{c}\text { Very Good } \\
\text { (SB) }\end{array}$ & $\mathrm{X}>420$ \\
\hline $\mathbf{2}$ & $\mathrm{Mi}+0.6 \mathrm{Sbi}<\mathrm{X}<\mathrm{Mi}$ & Good $(\mathrm{B})$ & $\begin{array}{c}340<\mathrm{X} \leq \\
420\end{array}$ \\
& $+1.8 \mathrm{Sbi}$ & & $260<\mathrm{X} \leq$ \\
$\mathbf{3}$ & $\mathrm{Mi}-\mathrm{Sbi} 0.6<\mathrm{x}<\mathrm{Mi}$ & Enough $(\mathrm{C})$ & 340 \\
& $+0.6 \mathrm{Sbi}$ & & $180<\mathrm{X} \leq$ \\
$\mathbf{4}$ & $\mathrm{Mi}-\mathrm{Sbi} 1.8<\mathrm{X}<\mathrm{Mi}-$ & Less $(\mathrm{K})$ & 260 \\
& $0.6 \mathrm{Sbi}$ & & $\mathrm{X} \leq 180$ \\
$\mathbf{5}$ & $\mathrm{X}<\mathrm{Mi}-1.8 \mathrm{Sbi}$ & Very Less & \\
& & (SK) & \\
\hline
\end{tabular}

\subsection{Field Trial (disseminate)}

Implementation of field trials conducted by the students' learning activities. Learning activities take place by using media that has been developed. Then the students were asked to comment on media products Bamboo Fraction learning it. The response of students to instructional media products includes several aspects, namely ease of understanding, independence aspect, the aspect of interest to the media, the aspect of expediency, and the aspects of ease of use. Overall student responses to the instructional media product by seven students can be seen in Table 5 .

Table 5 Student feedback on the Quality of Products

\begin{tabular}{|llcc|}
\hline No. & \multicolumn{1}{c}{ Aspect } & $\begin{array}{c}\text { total } \\
\text { Ratings }\end{array}$ & $\begin{array}{c}\text { percentage } \\
\text { Rate }\end{array}$ \\
\hline $\mathbf{1}$ & $\begin{array}{l}\text { ease } \\
\text { understanding }\end{array}$ & 86 & $86 \%$ \\
\hline $\mathbf{2}$ & autonomy & 91 & $91 \%$ \\
\hline $\mathbf{3}$ & interest in the media & 93 & $93 \%$ \\
\hline $\mathbf{4}$ & expediency & 86 & $86 \%$ \\
\hline $\mathbf{5}$ & ease of use & 88 & $88 \%$ \\
\hline & & $\mathbf{4 4 4}$ & $\mathbf{8 8 . 8 \%}$ \\
\hline
\end{tabular}

The average total score of assessment of students is 444 . Based on these data, instructional media product quality. Bamboo Fraction based on the responses of students are classified as very good (444> 420). Such assessments, if translated with an explanation of each aspect is as follows, Part ease of understanding, as an indication that the media Bamboo Fraction math learning can be used to easily understand the concept of early fractions. Part independence, as an indication that the media can be used to study independently. Students can independently use instructional media to learn the basic material fractions. Part interest in the media, as an indication that, when media that have developed easy to use will make the students have a high enthusiasm and interest in using the media. Part of expediency, as an indication that, Fraction Bamboo media can help students in understanding the concept of fractions material with a more pleasant way. Part ease of use, as an indication that the media Bamboo Fraction is easy to use independently outside learning activities. 
Five Grade Students of Elementary School," in 2nd Interntional Conference of Communication Science Research, 2018, pp. 173-177.

[10] S. Prasetyo, "Pengembangan Media Pembelajaran IPA Berbasis Android Untuk Siswa SD/MI," J. Madrasah Ibtidaiyah Educ., vol. 1, no. 1, pp. 121-140, 2017.

[11] A. P. Sari and A. Setiawan, "International Journal of Active Learning The Development of Internet-Based Economic Learning Media using Moodle Approach," Int. J. Act. Learn., vol. 3, no. 2, pp. 100-109, 2018.

[12] T. K. Dewi and R. Yuliana, "Pengambangan Media Pembelajaran Scrapbook Materi Karangan Deskripsi Mata Pelajaran Bahasa Indonesia Kelas III Sekolah Dasar," J. Ilm. Kependidikan, vol. 9, no. 1, pp. 19-25, 2018.

[13] D. Y. Saputri, Rukayah, and M. Indriayu, "Need Assessment of Interactive Multimedia Based on Game in Elementary School : A Challenge into Learning in 21 st Century," Int. J. Educ. Res. Rev., vol. 3, no. 3, pp. 18, 2018.

[14] G. Hartanti, "Keberadaan Material Bambu Sebagai Substitusi Material Kayu Pada Penerapan Desain Interior Dan Arsitektur," Humaniora, vol. 1, no. 1, pp. 11-19, 2010.

[15] E. Arsad, “Teknologi Pengolahan Dan Manfaat Bambu," J. Ris. Ind. Has. Hutan, vol. 7, no. 1, pp. 45$52,2015$.

[16] Risnawati, Z. Amir, and N. Sari, "The development of learning media based on visual, auditory, and kinesthetic ( VAK ) approach to facilitate students' mathematical understanding ability The development of learning media based on visual, auditory , and kinesthetic ( VAK ) approach to," in 2nd International Conference on Statitics, Teaching, and Research, 2018, pp. 1-8.

[17] E. Mulyatiningsih, Metode Penelitian Terapan Bidang Pendidikan. Bandung: Alfabeta, 2014.
[7] I. M. Suarjana, D. P. Parmiti, and P. E. A. Safitri, "Analisis Kesulitan Siswa Dalam Menyelesaikan Operasi Hitung Pecahan Siswa Sekolah Dasar," Int. J. Elem. Educ., vol. 2, no. 2, pp. 144-155, 2018.

[8] B. Lazić, S. Abramovich, M. Mrđa, and D. A. Romano, "On the Teaching and Learning of Fractions through a Conceptual Generalization Approach," Int. Electron. J. Math. Educ., vol. 12, no. 3, pp. 749-767, 2017.

[9] M. Akhyar, Djono, and Y. D. Puspitarini,

"Developing Powtoon-Based Video Learning Media for 